\title{
ENDOSCOPIC ULTRASOUND (EUS) DIAGNOSIS OF BLUNT PANCREATIC TRAUMA ASSOCIATED TO THE SUPERIOR MESENTERIC VEIN THROMBOSIS
}

\author{
Diagnóstico de trauma pancreático associado à trombose da veia mesentérica feito através da \\ ultrassonografia endoscópica
}

Everson L. A. ARTIFON ${ }^{1}$, Décio S. COUTO-JÚNIOR ${ }^{1}$, Gustavo P. FRAGA ${ }^{2}$, Paulo SAKAI ${ }^{1}$, Samir RASSLAN ${ }^{1}$

From ${ }^{1}$ Gastroenterology and Surgery Department, University of São Paulo School of Medicine (USP), São Paulo, SP, Brasil and ${ }^{2}$ Surgery Department, State University of Campinas (UNICAMP), Campinas, SP, Brasil.

HEADINGS-Venous trombosis. Mesenteric artery, superior.

\section{Correspondência:}

Paulo Sakai.

e-mail: paulosakai@terra.com.br

Fonte de financiamento: não há

Conflito de interesses: não há

Recebido para publicação: 14/03/2009

Aceito para publicação: 03/09/2009

DESCRTORES - Trombose venosa. Artéria mesentérica superior.
ABSTRACT - Background - Blunt pancreatic injuries occur when a high-energy crushing force is applied to the upper abdomen. In adults, the majority of blunt pancreatic injuries result from motor vehicle accidents. Case report - Male with 32 years old had a high-energy crushing history in witch he was pressured by the chest on the front car area. His life signs demonstrated to be regular. Ct scan demonstrated body pancreatic edema. All routine laboratorial exams were normal, EUS revealed pancreatic lesion grade II without involvement of the pancreatic duct and an impressive superior mesenteric vein thrombosis. He was sustained by means of anti- coagulation for about two months and after that time the multislice CT scan showed a mesenteric vein recanalization and a normal pancreatic parenchyma. The patient had an uneventfull follow-up. Conclusion - Patients presenting possible pancreatic trauma associated to superior mesenteric vein thrombosis, EUS must be used firstly.

RESUMO - Introdução - Traumas pancreáticos fechados ocorrem em acidentes que promovem força intensa no abdome superior, principalmente em acidentes automobilísticos. Relato do caso - Homem de 32 anos foi jogado contra a área frontal de seu automóvel. Seus sinais vitais eram normais. CT mostrou edema pancreático. EUS mostrou lesão pancreática grau II sem envolvimento do ducto pancreático, mas com impressionante trombose da veia mesentérica superior. Ele foi mantido com anticoagulants por dois meses e após este period novo scan mostrou recanalização e pâncreas normal. Teve seguimento favorável. Conclusão - Paciente apresentando edema pancreático associado a possível trombose de veia mesentérica superior deve ser submetido à EUS para monitorização e acompanhamento.

\section{INTRODUCTION}

B lunt pancreatic injuries occur when a high-energy crushing force is applied to the upper abdomen. In adults, the majority of blunt pancreatic injuries result from motor vehicle accidents ${ }^{9}$. Some cases of acute pancreatic injury may be difficult to diagnose by conventional imaging studies including CT and transabdominal ultrasonography. Endoscopic ultrasonography (EUS) provides high resolution of the pancreas and may be useful for diagnosing pancreatic trauma, as has been reported for the diagnosis of pancreatic cancer ${ }^{11}$, pancreatic endocrine tumor ${ }^{6}$, and acute pancreatitis ${ }^{8}$.

\section{CASE REPORT}

Male with 32 years old had a high-energy crushing history in witch he was pressured by the chest on the front car area. He was then promptly subjected to the Surgery Emergency Room in the Hospital Estadual de Sapopemba FMUSP with volemic shock (low level). His life signs demonstrated to be regular. However, it was found superior abdominal pain during examination. Ct scan demonstrated body pancreatic edema. All routine laboratorial exams were 
normal, despite of amylase that was found $410 \mathrm{~mL} / \mathrm{dL}$. In the present case it was suspected a solid abdominal trauma organ lesio and then EUS was indicated due to stability of the general conditions during outcome evaluation. The EUS revealed pancreatic lesion grade II without involvement of the pancreatic duct (Figure 1) and an impressive superior mesenteric vein thrombosis (Figure 2). The patient was sustained by means of anti- coagulation for about two months and after that time the multislice CT scan showed a mesenteric vein recanalization and a normal pancreatic parenchyma. The patient had an uneventfull follow-up.

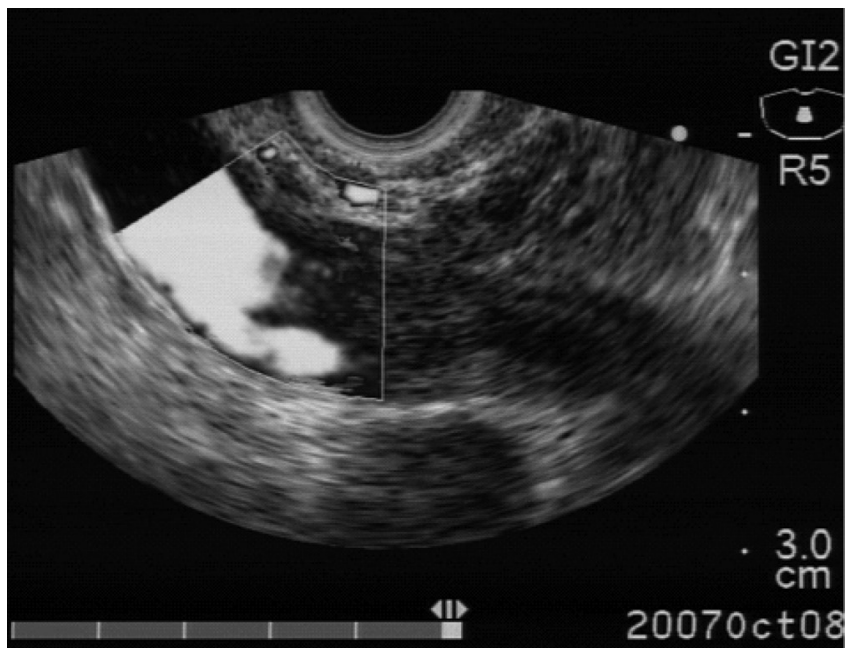

FIGURE 1 - EUS image showing the superior mesenteric vein thrombosis

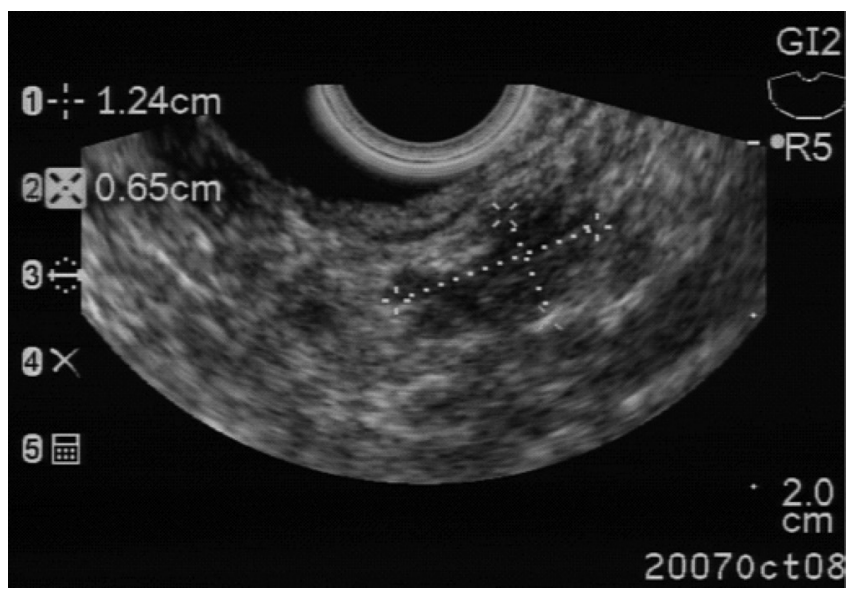

FIGURE 2 - EUS image showing an irregular image corresponding to the pancreas lesions very close to the superior mesenteric vein thrombosis, but no evidence of pancreatic duct lesion.

\section{DISCUSSION}

Mesenteric vein thrombosis symptoms are often non-specific but include abdominal pain, nausea, vomiting, diarrhea and gastrointestinal bleeding. In some patients, abdominal pain seems out of proportion to relatively minor findings on physical examination. Other patients may have symptoms that gradually increase in severity over several days prior to medical consultation?

Although the highest concentration amylase is not a reliable indication of pancreatic trauma, same authors recognize ${ }^{1,9}$ the association between hyperamylasemia and pancreatic trauma. However Vitale et al. ${ }^{10}$, in an interesting report in which serum amylase was mensuraded in 60 patients with isolated blunt head trauma, specifically exclusing patients with abdominal trauma, suggested a central nervous system regulation pathway of serum amylase levels and implying that it is not a reliable indication of pancreatic injury.

Although transabdominal ultrasonography has the advantages of easy and fast performance, ultrasonography often has inadequate visualization of the pancreas and is somewhat less sensitive for diagnosing pancreatic trauma than $\mathrm{CT}^{4}$.

Abdominal CT scan have a reported sensitivity and specificity as high as $80 \%$ in diagnosing pancreatic injury, although the accuracy of this examination is largely dependent on interpreter experience, quality of the scanner and the time from injury ${ }^{3,5}$. It has the disadvantages of complicated usage, limited repeatability, and radiation exposure. Additionally, the load of contrast material might worsen the renal insufficiency associated with pancreatic injury ${ }^{8}$.

In patients hemodinamicaly stable, EUS has some advantages due to can be positioned very close to the pancreas and mesenteroportal confluence. Dupplex scan resource, accuracy of the images, mobility of the equipment, absence of radiation exposure, and no requirement of contrast material are the EUS advantages.

In whom $C T$ fails to detect pancreatic injury despite abdominal pain and persistent hyperamylasemia, EUS may demonstrate pancreatic lesions. EUS may play a role in the evaluation of blunt pancreatic trauma, especially if a CT scan is negative or equivocal in patients suspected of pancreatic trauma or if CT study is not possible because of the inability to move such patients ${ }^{8}$. Moreover, EUS can be repeatedly performed at the bedside.

\section{CONCLUSION}

Patients presenting possible pancreatic trauma associated to superior mesenteric vein thrombosis, EUS must be used firstly.

\section{REFERENCES}

1. Bonwwan $D$, Weaver $D$, Walt $A$. Serum amylase and its isoenzymas: $A$ classification of their implication in trauma. J. Trauma 24(7): 573, 1984.

2. Chiu HH, ChaoCC, Tsai CC et al. Gastrointestinal: Mesenteric venous thrombosis. Journal of Gastroenterology and Hepatology 2003; 18, 1209 
3. Jeffrey RB Jr, Federle MP, Crass RA. Computed tomography of pancreatic trauma. Radiology. 1983 May;147(2):491-4.

4. Jeffrey RB, Laing FC, Wing VW. Ultrasound in acute pancreatic trauma. Gastrointest Radiol 1986;11:44-6

5. Peitzman AB, Makaroun MS, Slasky BS, Ritter P. Prospective study of computed tomography in initial management of blunt abdominal trauma. J Trauma. 1986 Jul;26(7):585-92.

6. Rösch T, Lightdale CJ, Botet JF, Boyce GA, Sivak MV Jr, Yasuda K, Heyder N, Palazzo L, Dancygier H, Schusdziarra V, et al. Localization of pancreatic endocrine tumors by endoscopic ultrasonography. N Engl J Med. 1992 Jun 25;326(26):1721-6.

7. Sugiyama M, Atomi $Y$, Kuroda A, Muto T, Wada N. Endoscopic ultrasonography for diagnosing blunt pancreatic trauma. Gastrointest Endosc. 1996 Dec;44(6):723-5.
8. Sugiyama M, Wada N, Atomi $Y$, Kuroda A, Muto T. Diagnosis of acute $p$ ancreatitis: value of endoscopic sonography. AJR Am J Roentgenol 1995;165:867-72

9. Takishima T, Sugimoto K, Hirata M, Asari Y, Ohwada T, Kakita A. Serum amylase level on admission in the diagnosis of blunt injury to the pancreas: its significance and limitations. Ann Surg. 1997 Jul;226(1):70-6

10. Vitale GC, Larson GM, Davidson PR, Bouwman DL, Weaver DW. Analysis of hyperamylasemia in patients with severe head injury. J Surg Res. 1987 Sep;43(3):226-33.

11. Yasuda K, Mukai H, Fujimoto S, Nakajima M, Kawai K. The diagnosis of pancreatic cancer by endoscopic ultrasonography. Gastrointest Endosc. 1988 Jan-Feb;34(1):1-8. 